\title{
A KOLOZSVÁRI PÉLDA DOKUMENTUMOK A KOLOZSVÁRI EGYETEMI MENZA MÜKÖDÉSÉRÖL ÉS DEBRECENI KAPCSOLATÁRÓL
}

\begin{abstract}
In the Footsteps of Kolozsvár. Documents on STUDENTS Work at tHe UnIVERSITY of DeBRECEN AND ITS CONNECTION WITH THE UNIVERSITY OF KOLOZSVAR. It's a well-known historical fact that the foundation of the students' canteen in the University of Debrecen was one of the first steps to establish a welfare organization in a hope to support hundreds of students in their studies between the two World Wars in Debrecen. Also widely known that under the guidance of Nandor Lang this students' canteen gained prosperity. At the same time, far less attention has been given to networks and relations in higher education underpinning this initiative. Láng asked assistance and information from the University of Kolozsvár which was the only provincial university in Hungary. The letter of Béla Posta which was written to Nándor Láng in December 20, 1916 and all of the attached documents are very rare and valuable sources of the history in both universities. The paper therefore can be considered as a novelty by giving an insight into the partnership of the University of Debrecen and Kolozsvár.
\end{abstract}

Debrecenben a Mensa Academica, vagyis az Egyetemi Diákasztal már az újonnan alakult felsőoktatási intézmény második tanévében (1915/16.) megkezdte működését. A hallgatók szervezett étkeztetését biztosító, az egyetem életéhez elengedhetetlenül hozzátartozó diákjóléti intézmény 1915. szeptember 16-án ${ }^{1}$ nyitotta meg kapuit, köszönhetően az egyetem és a Vallás- és Közoktatásügyi Minisztérium támogatása mellett a nagyvonalú Gárdos János Alapítványnak. ${ }^{2} \mathrm{~A}$ közoktatási tárca éves államsegélye és ez az alap jelentette a menza müködésének egyetlen biztos bevételi forrását, elősegítve ezáltal azt a célt, hogy ez a diákjóléti intézmény a legszegényebb hallgatók kedvezményes és indokolt esetben ingyenes étkeztetésével kiterjedt diáksegélyezést is folytasson.

${ }^{1}$ Egyetemi Tanácsülési Jegyzőkönyvek [továbbiakban: E.T. Jegyzökönyvek] 1915/16. tanév, I. rendes ülés. 1915. szeptember 30., 23. szám. 8. etsz., b. pont - Magyar Nemzeti Levéltár Hajdú-Bihar Megyei Levéltár [továbbiakban: MNL HBML] VIII. 1/a. 1.k.

2 A történet 1894. január 11-ére nyúlik vissza, amikor egy budapesti orvos, dr. Gárdos János neje, a nem sokkal később, 1894. február 26-án elhalálozott özv. Gárdos Jándosné szül. Andrássy Júlia végrendeletében az állam által alapítandó harmadik tudományegyetemen létesítendő menza céljaira jelentős adományt tett. Mivel azonban az 1912. évi XXXVI. törvénycikk Debrecenben és Pozsonyban is egyetem felállításáról rendelkezett, az a minisztériumi döntés született, hogy az ún. „Gárdos-alap” tiszta jövedelmét kettéosztják, és az fele-fele részben fog a két létesítendő menza rendelkezésére állni. - Vö. VKM. 104.706/1913. - A Debreczeni Magyar Királyi Tudományegyetem Évkönyve az 1915/16. tanévröl, Debrecen, 1917, 125-126. 
A Mensa Academica első gondnoka Milleker Rezső, pénztárnoka pedig Kölönte Géza, az egyetem hivatalban lévő quaestora lett, majd két évvel később az Egyetemi Diákasztal élére az a legendássá vált Láng Nándor professzor került, aki az egész debreceni diáksegélyezési rendszer fejlődését meghatározta. Láng 1917. június 26-án kapott megbízást az Egyetemi Tanácstól a menza ügyeit intéző felügyelőbizottság vezetésére. ${ }^{3}$

A debreceni Mensa Academica Láng vezetésével a legjobban működő diákjóléti intézmények közé tartozott az országban, s megszervezéséről, elhelyezésének körülményeiről, költözéseiről, alapszabályairól, diákjóléti tevékenységéről, válságos időszakairól, külföldi kapcsolatairól viszonylag sokat tudunk. Jóval kevésbé ismert viszont, hogy az intézmény müködésének rendjét meghatározó, alapszabályait lefektető és a menza arculatát végső formába öntő Láng Nándor miként látott hozzá a felelősségteljes munkához. Mennyire támaszkodott kizárólag a saját és a felügyelőbizottság tagjainak elképzeléseire, amikor Debrecenben a Mensa Academica kialakításába és stabil müködési struktúrájának a megszervezésébe aktívan bekapcsolódott? Volt-e előtte valamilyen példa, s ha igen, akkor milyen mértékben igyekezett átvenni a máshol már bevált mechanizmusokat?

Ezeknek a kérdéseknek a megválaszolásához visznek közelebb azok az alábbiakban először publikált dokumentumok, amelyek egyértelműen arról tanúskodnak, hogy Láng bölcs előrelátással igyekezett minél inkább kiküszöbölni azokat a hibákat, amelyek egy teljesen új intézmény működésének a kezdetén óhatatlanul előfordulhatnak. Ennek érdekében még mint az 1916/17-es tanév rektora, segítséget és útmutatást kért onnan, ahol megfelelő szakmai tudással és kellő gyakorlati tapasztalattal rendelkeztek, és bizalommal fordult ahhoz az intézményhez, ahonnan a debreceni Egyetemi Diákasztal megszervezéséhez támogatást, bátorítást és önzetlen segítséget remélhetett, Kolozsvárhoz. ${ }^{4}$

A pozsonyi és debreceni egyetem 1912-es megalapításáig ugyanis egyedül az 1872. évi XIX. törvénycikkel felállított kolozsvári m. kir. Ferencz József-tudományegyetemen folyt egyetemi képzés Budapesten kívül. Kolozsvár pedig mint az ország egyetlen vidéki egyeteme, saját maga kellett kialakítsa azokat az intézményeket, és megteremtse azokat az infrastrukturális feltételeket, amelyek egy egyetem működéséhez szükségesek. Ebből a megfontolásból kiindulva Láng Nándor 1916. december 12-én átiratot intézett

${ }^{3}$ A bizottság alelnöke Csánki Benjámin, pénztárnoka Kölönte Géza, míg gondnoka Milleker Rezső lett. A tudománykarok képviseletében vett részt a felügyelőbizottság munkájában a teológiai karról Erdős József és Ferenczy Gyula, a jogi karról Bacsó Jenő és Szentpéteri Kun Béla, míg a Bölcsészettudományi Karról Darkó Jenő és Pokoly József. Vö. E.T. Jegyzőkönyvek 1916/17. tanév, XV. rendes ülés. 1917. június 26., 168. szám. - MNL HBML VIII. 1/a. 1. k.; valamint: A debreceni m. kir. Tudományegyetem Évkönyve és Almanachja az 1918/19. tanévröl [Kéziratos évkönyv], 129.

${ }^{4}$ A két egyetem között az első szorosabb kapcsolatfelvételre információim szerint 1915 áprilisában került sor, amikor a Kolozsvári Egyetemi Könyvtár átiratban fordult a Debreceni m. kir. Tudományegyetem Tanácsához. Az átirattal együtt megküldte Debrecenbe a kolozsvári egyetem hivatalos kiadványait, $\mathrm{s}$ egyben kérte, hogy a tanács juttassa el részére a debreceni egyetemi kiadványokat, $\mathrm{s}$ „ezzel a csereviszonyt elfogadni és állandósitani sziveskedjék." E. T. Jegyzökönyvek 1914/15. tanév, V. rendes ülés. 1915. április 16., 35. szám. 498. etsz. - MNL HBML VIII. 1/a. 1. k. 
Dr. Pósta Bélához, a Kolozsvári Egyetemi Diákasztal felügyelőbizottságának elnökéhez, remélve, hogy iránymutatást és hasznos tanácsokat kaphat a debreceni testvérintézmény szervezetének kialakításához és alapszabályainak megszövegezéséhez. ${ }^{5}$

Nyolc nappal az átirat megírását követően már meg is született Pósta Béla terjedelmes válaszlevele, amely pótolhatatlan és máshonnan meg nem ismerhető részleteket közölt a kolozsvári Mensa Academica müködésével, szervezeti felépítésével, belső rendjével és a hallgatók mindennapi életével kapcsolatban. A levél forrásértéke és a debreceni intézmény megalapításában játszott szerepe miatt teljes egészében közlésre kerül, akárcsak a Kolozsvári Egyetemi Diákasztal Házirendje, valamint az a három gépelt oldal terjedelmű tájékoztató (Egyetemi Diákasztal [Mensa Academica] Kolozsvárt), amelyet Pósta Béla mellékelten küldött Lángnak. A küldeményben szerepelt még egy, az Egyetemi Tanács részére készült, függelékkel együtt 16 oldalas jelentés is a kolozsvári Diákasztal 1903/1904. tanév második félévi működéséről. ${ }^{6}$

A forrásközlésként szereplö dokumentumokkal kapcsolatban fontos kiemelni, hogy belőlük egy olyan szervezetten működő menza képe bontakozik ki, amely előképe a debreceni Mensa Academicának, és a szervezeti felépítés véglegesítése, valamint az alapszabályok lefektetése során konkrét, közvetlen példának tekinthető. Ezt támasztja alá az említett jelentés is, amelyben számos olyan elem fordul elő, amely később a debreceni Mensa Academica müködése során is megjelent. Egyértelműen kolozsvári mintát követett maga a menza vezetésével megbízott felügyelőbizottság létrehozása is Debrecenben. A Mensa Academicától elkülönülten, de ugyanennek a felügyelőbizottságnak a hatáskörébe tartozott az 1921-től működő Tisza István Internátus is, sőt a két intézmény sokáig egy épületben került elhelyezésre. Kolozsváron, mint a megküldött dokumentumokból kiderült, a menza egyben internátusként is szolgált az arra érdemesnek talált kevesek számára. ${ }^{7}$

Annak ellenére, hogy Pósta Béla 1916. december 20-án kelt levelében megjegyezte, hogy „a kolozsvári Egyetemi Diákasztalt aligha vehetik Debreczenben mintául”, rét hasonlóságok arra mutatnak, hogy Láng Nándor igenis működőképes mintának tekintette a kolozsvári Mensa Academicát.

A Ferenc József Tudományegyetem Tanácsa számára írt beszámolóból tudjuk például, hogy ott az Egyetemi Diákasztal házi kezelésbe vétele az 1903/1904-es tanévben, Apáthy István rektorsága idején történt meg. ${ }^{9}$ Debrecenben viszont az addig saját használatban lévő üzem 1918-ban került egy vállalkozóhoz, miután a felügyelő-bizott-

5 Láng Nándor 1916. december 12-én kelt levelének a szövege eddig nem került elő.

${ }^{6}$ „Az Egyetemi Diákasztal fólügyelo" [sic] bizottságának jelentése a házi-kezelésbe vett Diákasztal elsö félévéröl, vagyis az 1903/4. tanév II. feléröl" - MNL HBML VIII. 1.b. 4.d. 449-1916/17. - Ennek a jelentésnek a közlése meghaladja a rendelkezésre álló terjedelmi kereteket.

7 Az épületben 42 hallgató számára 22 diákszoba állt rendelkezésre. - Egyetemi Diákasztal (Mensa Academica) Kolozsvárt, 2. - MNL HBML VIII. 1.b. 4.d. 449-1916/17.

8 A kolozsvári Mensa Academica vezetőjének, Pósta Bélának levele Láng Nándorhoz, 1. - MNL HBML VIII. 1.b. 4.d. 449-1916/17.

9 Az Egyetemi Diákasztal fölügyelö bizottságának jelentése..., i. m., 1. - MNL HBML VIII. 1.b. 4.d. 449-1916/17. 
ság szerződést kötött Törzsök Ida úrhölggyel, aki egy adag ebéd-vacsora elóállítását 3 korona 80 fillérért vállalta, míg a saját üzemben történő elóállítás azt megelőzően 5 korona 6 fillérbe került. ${ }^{10} \mathrm{~A}$ bizottság tagjai ebben az időben személyesen felügyelték az ellátást, és rendszeresen ellenőrizték a kiszolgált étel mennyiségét és minőségét. Végül a debreceni Egyetemi Diákasztal a Törzsök Idával kötött szerződést Láng Nándor kezdeményezésére mondta fel. Az 1921/22-es tanévtől kezdődően az üzemi konyhát a menza saját kezelésbe vette, legfóképpen abból a célból, hogy a „vállalkozó haszna a koszt javitására fordittassék" ${ }^{11}$ Az átállás kezdetben számos gondot okozott, de végül gazdaságilag is megtérülőnek bizonyult, és az idő Láng Nándort igazolta. ${ }^{12}$

Az 1903/1904-es tanévről szóló kolozsvári jelentésben feltűnt továbbá az a menzadíj is, amit minden egyetemi hallgatónak a félévi beiratkozások alkalmával kellett fizetni a menza javára. Ezen egykoronás díj alóli felmentésre nem volt lehetőség. ${ }^{13}$ Debrecenben az 1917/18-as tanévben vetődött fel a menzadíj gondolata, miután a Mensa Academica felügyelőbizottsága a költségvetési előirányzatban 8900 korona fedezeti hiányt mutatott ki, s az Egyetemi Tanács közvetítésével rendkívüli segélyt kellett kérni. ${ }^{14}$ A helyzet hosszú távú orvoslása érdekében a tanács még ugyanazon az 1917. októberi ülésen felterjesztette a felügyelőbizottság javaslatát, miszerint „a kolozsvári és pozsonyi egyetemeken fennálló gyakorlatnak megfelelöen engedje meg Öexcellenciája, hogy az egyetemünkön beiratkozó hallgatóktól a Mensa javára a beiratkozások alkalmával $1 K$ $50 f$ mensa-dij szedessék" ${ }^{15}$

A menzadíj ettől kezdve szervesen beépült a Debrecenben a féléves beiratkozások alkalmával szedett egyetemi mellékdíjak közé, $s$ a pengő bevezetésével összegét 4 pengőben határozták meg, amit a korszakban mindössze egyetlen alkalommal emeltek fel. ${ }^{16}$ Az 1930/31-es tanévtől félévenként 6 pengőt kellett a hallgatóknak ilyen címen fizetni. ${ }^{17}$

${ }^{10}$ A Debreczeni Magyar Királyi Tudományegyetem Évkönyve az 1917-1918. tanévről. Debrecen, 1918., 55. - Jelentés a debreceni Egyetemi Diákasztal - Mensa Academica - 1917-18. tanévi müködéséről és állapotáról.

${ }^{11}$ Az idézet Láng egyik későbbi jelentéséből származik. - A Debreceni m. kir. Tisza István Tudományegyetem Évkönyve és Almanachja az 1929/1930. tanévről, Debrecen, 1931., 346. - Jelentés a Mensa Academica és a Tisza-Internátus 1929-30. tanévi működéséről.

12 „Az üzemváltozás sok gond és nehézséggel járt. A gazdasági év elörehaladottsága, a Mensa silány, selejtes és hiányos felszerelése okozta jórészt ezt. Azonban a fáradtság bö jutalmat nyert: a Mensánkat látogató ifjúságunk száma megkétszerezödött, söt sokszor megháromszorozódott. A panaszok megszüntek [sic]. [...] Ha Mensánk vállalatban marad, a fenntartást ilyen létszám mellett, sokkal silányabb koszttal sem birta volna el." - A Debreceni m. kir. Tisza István Tudományegyetem Évkönyve és Almanachja az 1921/1922. tanévröl, Debrecen, 1932, 134, 136-137. - Láng Nándor jelentése a Mensa Academica működéséről.

${ }_{13}$ Az Egyetemi Diákasztal fölügyelo" bizottságának jelentése..., i. m., 2-3.

${ }_{14}$ E.T. Jegyzökönyvek 1917/18. tanév, II. rendes ülés. 1917. október 27., 17. szám. 319. etsz. - MNL HBML VIII. 1/a. 1. k.

15 Uo., 18. szám. 320. etsz. - MNL HBML VIII. 1/a. 1. k.

${ }_{16}$ MNL HBML VIII. 2. 10.d. 216-217-1926/27. Q. szám.

${ }^{17}$ MNL HBML VIII. 2. 14.d. 241-1930/31. Q. szám. 
A kolozsvári Egyetemi Diákasztal sajátossága volt viszont a menza mellé rendelt hölgybizottság, amelynek fó célja a korábbi gyüjtőbizottság felélesztése, valamint a belső felügyelet biztosítása volt. Az egyetemi tanárok és tanársegédek feleségeiből alakult bizottság elnöke Pásztóry Mórné, egyik alelnöke pedig dr. Apáthy Istvánné, a rektor felesége volt. A hölgybizottság megalakulásáról és jelentőségéről a következőket olvashatjuk a jelentésben:

„1903. deczember hó 6-án alakúlt [sic] meg egyetemünk tanárainak, magántanárainak és tanársegédek nejeiböl a hölgybizottság, a mely [sic] kiegészitette magát városunk intelligens osztályának az egyetemen kivül [sic] álló hölgyeiböl. [...] Annyi jóakaratot, oly serény készséget és lekötelezö fáradtságot áldozott a hölgybizottság minden egyes tagja Mensánk elárvult ügyének, a mennyit [sic] kellöképpen megköszönni igazán nem is lehet [...] A hölgybizottság müködése mindjárt kezdettöl kettös irányuvá [sic] vált. Az egyik irány, a Mensa alaptókéjére való gyüjtést, a másik a Mensa házi kezelése körül [sic] fölmerülö teendök ellátását ölelte fel." 18

Az 1903/1904. tanévben került sor az 1904. június 28-án kelt jelentés szerint az ekkor egyszerre 200 hallgató befogadására képes kolozsvári Egyetemi Diákasztal mellett működo, diákokból álló „Mensa Szövetség” megalakítására is. ${ }^{19}$ A felügyelőbizottság ezzel a hallgatók aktív szerepvállalását igyekezett elősegíteni a menza működésében, hogy így is az életre neveljen, és hozzájáruljon a diákok felelősségérzetének a növeléséhez:

„Akartuk, hogy az ifuiság tanúljon [sic] meg dolgozni a közért egyrészt, másrészt ő maga is lássa a mindennap leküzdendön nehézségeket, s mikor ezen nehézségek leküzdésében részt vesz, egyúttal megtanúlja[sic] magáénak tartani és megbecsülni [sic] az intézményt magát. E végböl alakitotta meg a felügy.-bizottság elnöke az egyetemi ifjak "Mensa Szövetségé«-t."20

A kezdeményezés végül nem váltotta be a hozzá füzött reményeket, s mint az Pósta Béla Lánghoz írt leveléből is kiderül, a szövetséget alig egy évi működés után fel kellett oszlatni. ${ }^{21}$ Jól működött viszont, és a debreceni menza is átvette az ebéd- és vacsorajegyek rendszerét, valamint a hozzá kapcsolódó inspekciós szolgálatot. Ennek a lényege

${ }^{18}$ Az Egyetemi Diákasztal fölügyelö bizottságának jelentése..., i. m., 4. - A kolozsvári hölgybizottság egyik legfontosabb kezdeményezésének a Mensa-estélyek tekinthetők, amelyek fó célja az adománygyűjtés volt. Maguk a napi felügyeletet ellátó hölgyek is az ügyelet napján 10-10 fillért voltak kötelesek a Mensa-perselybe szolgáltatni: „Már a második ülésükön elhatározzák a hölgyek a Mensa-estélyek rendezését. Ezen estélyekre megállapitják a menut, maguk közt szedik össze a theához szükségeseket; maguk rendezkednek, elvégeznek mindent a terités legapróbb részletéig; vendégeket toborzanak, maguk árulják a jegyeket; berendezéseink fogyatékosságát jó szivvel leplezik, mert maguk tálalnak, söt fel is szolgálnak, mint igazi szamaritanök. [...] E bizottság vállalja magára a napi étlapnak idöröl-idöre [sic] való összeállitását. Már második ülésében [sic] elhatározza, hogy a fözés, kiszolgálás, a rend és tisztaság ellenörzése végett naponkint két hölgy tart inspectiót a Mensa helyiségeiben. [...] Az ö felügyeletük áldó takarója a Mensa szegénységének.” - Az Egyetemi Diákasztal fölügyelöbizottságának jelentése..., i. m., 4-5.

19 1916-ban a kolozsvári Mensa Academica már 300 hallgató egyidejű étkeztetését tette lehetővé. - Vö. Egyetemi Diákasztal (Mensa Academica) Kolozsvárt, 2. - MNL HBML VIII. 1.b. 4.d. 449-1916/17.

${ }^{20}$ Az Egyetemi Diákasztal fölügyelo" bizottságának jelentése..., i. m., 2.

${ }^{21}$ A kolozsvári Mensa Academica vezetójének, Pósta Bélának levele Láng Nándorhoz, 2. - MNL HBML VIII. 1.b. 4.d. 449-1916/17. 
abban állt, hogy az étkezők ellenőrzését és az ételadagok kiosztását az ingyenesen vagy kedvezményesen étkezőkből álló inspekciósok végezték napi beosztás szerint. Láng Nándor egyik, 1917. februári átirata így tanúskodik a jegyrendszer debreceni gyakorlatáról:

„A Mensán bárki csak ugy [sic] étkezhetik, ha jegyét elöre meguáltja, ennek ellenörzésére az ingyenes tagok felváltva inspektiós szolgálatot teljesitenek. "22

A kolozsvári Mensa Academica sajátossága volt ellenben, hogy amellett, hogy szállást is biztosított a hallgatóknak, a bentlakó diákok életét is szabályozta világos korlátokat állítva eléjük. A források alapján kifejezetten sikeresnek tekinthető a mindennapjaikat felügyelő „fellow-rendszer”, amely a hallgatói élet kordában tartását egy minden szempontból feddhetetlen, tekintélyét viselkedésével és tudományos teljesítményével is kivívó, a diákokkal közvetlen, bensőséges viszonyt ápoló személyre bízta. A levél tanúsága szerint a hallgatók hétköznapjait színesítette továbbá a kolozsvári menzán bevezetett vasárnap délutáni fogadóestélyek szokása, amely találkozási és ismerkedési lehetőséget is biztosított az egyetemre járó fiatalurak és a városi úri családok leányai között.

A házirendben lefektetett szabályok tiltották viszont a kártyát és a szerencsejátékot, a házalást, a koldulást, kutya, macska vagy baromfi tartását, a dohányzást és a szivarozást ellenben engedélyezték, amennyiben az hamutartó használatával történt. Kolozsvári sajátosságnak tekinthető a házirendnek az a pontja, amely a legszigorúbb szankciókat helyezte kilátásba a magyar nyelvhasználat követelménye ellen vétőkkel szemben. ${ }^{23}$ A diákok kényelmét szolgálták viszont a szobák tisztántartását és a ruhák tisztítását végző komornyikok, valamint a rendelkezésükre álló kifutószolgák. A lakásdíjat és a mosási díjakat a titkárnál kellett kifizetni, míg a kazánház és a hozzátartozó helyiségek, valamint a kapu kulcsa a gépész-házmester felügyelete alá tartoztak. ${ }^{24}$

A kolozsvári menza vezetőjével történő kapcsolatfelvétel tehát számos hasznos információval szolgált Láng számára a Mensa Academica működési struktúrájának a kialakításához. Ha figyelmesen elolvassuk a most következő, páratlan forrásértékkel bíró dokumentumok szövegét, akkor megfigyelhetjük a fogalmazás módjában tetten érhető hasonlóságokat, sőt egyes szakaszok szó szerinti átvételét a Debreceni Egyetemi Diákasztal Alapszabályainak megszövegezésekor. ${ }^{25} \mathrm{~A}$ közölt források azonban önmagukban, a debreceni vonatkozásoktól eltekintve is jelentősek, a végnapjait élő kolozsvári magyar egyetem diákéletébe és a hosszú ideig egyetlen vidéki egyetemváros mindennapjaiba engednek bepillantást.

22 Láng Nándor átirata Milleker Rezsöhöz, a Mensa Academica vezetöjéhez, 1917. február 14., 2. - MNL HBML VIII. 2. 2.d. 106-1916/17. Q. szám.

${ }^{23}$ A Kolozsvári Egyetemi Diákasztal Házirendjének 29. \$-a szerint: „Az étkező helyiségekben csak magyarul szabad beszélni, aki ez ellen vét, azt azonnal és örökre kitiltjuk összes helyiségeinkböl." - Kolozsvári Egyetemi Diákasztal Házirend, 29.\$. - MNL HBML VIII. 1.b. 4.d. 449-1916/17.

${ }^{24}$ A házirend szerint az összes konyhai alkalmazott a gazdasszony, minden más szolga a gépész-házmester irányítása alatt állt. - Kolozsvári Egyetemi Diákasztal Házirend, 13. \$. - MNL HBML VIII. 1.b. 4.d. 449-1916/17.

25 Vö. KIrály Sándor, A Debreceni Egyetemi Diákasztal (Mensa Academica) Alapszabályai = Közlemények a Debreceni Tudományegyetem Történetéből IV., szerk. HoLlósı Gábor, Debrecen, 2006., 77-83. 
A kolozsvári Mensa Academica vezetőjének, Pósta Bélának levele Láng Nándorhoz ${ }^{26}$

\author{
„Nagyságos Dr. Láng Nándor úrnak, \\ a debreczeni magyar tudományegyetem rektora
}

Igen tisztelt Professzor Úr!

Folyó hó 12-én kelt 382-916/17. számú nagybecsü átiratát a debreczeni Egyetemi Diákasztal szervezete és alapszabályai tárgyában ma vettem kézhez. Különös örömöt szerzett vele nekem, mert az a tény, amelyet ebböl az átiratból tudtam csak meg, hogy akadt magyar ember, aki a debreczeni és a pozsonyi egyetemeken létesitendö Diákasztalra kb. egy milliós alapitványt tett, valóban olyan fölemelö jelensége társadalmunk emelkedö irányának, amelyet nálam jobban alig méltányolhat valaki. Aggodó lélekkel kisértem figyelemmel a két új egyetemnek ügyét, mert én - jóllehet a kolozsvári egyetem alapitásának 27-ik esztendejében ${ }^{27}$ kerültem a második magyar egyetemre, mégis még nagyon keserves állapotokat találtam itt és még nagyon sok nyomorúságot és küzdelmet kellett átélnem, söt ezeknek sora bizonyos tekintetekben még ma is folytatódik. Tudom tehát, hogy milyen nehézségek leküzdésével kell az egészen új alapitású egyetemeknek megküzdeniök és mert lelkemnek minden erejével szivesen segitenék, jól tudván ezeknek az új alapitásoknak végtelen fontosságát nemzetünk jövöje szempontjából - kimondhatatlan öröm nekem látni azt, hogy egy erös magyar társadalom is áll a leküzdendö nehézségeknek szolgálatában.

Sokat vártam fóképen a debreczeni egyetemtöl, különösen azóta, hogy legutolsó Debreczenben való idözésemkor a város közmüvelödési tanácsosa ${ }^{28}$ megmutogatta nekem az új egyetemnek helyét; elmondotta, hogy mi mindent kiván a város is tenni az egyetemnek mentül nagyobb virágzása érdekében, mert 17 évet töltvén szegény, szerencsétlen Erdélyünkben elszoktam már az áldozatra kész magyar társadalomnak attól a képétöl, amelyet én - az alföldi ember - odahaza megszoktam. Itt a magyar társadalomnak más a képe. Csüggeteg lemondás, fájó megalkuvás minden képtelenséggel, visszahúzódás a legsajátabb egyéni törekvéseknek megvalósitása terére, még pedig tisztán a körülmények kényszerü nyomása alatt. Elképzelheti, hogy ehhez szokott szememnek milyen káprázatos fény volt a debreczeni társadalomnak eröteljességét látni a közmüvelödési tanácsos úr elöadásában és milyen jól esik most újabb jelenségét látni annak az életrevalóságnak, amely egyetlen reménységünk.

A kolozsvári Egyetemi Diákasztalt aligha vehetik Debreczenben mintául.

Ennek az intézménynek azokba a társadalmi viszonyokba kellett beléilleszkednie, amelyek - fájdalom - itt vannak és minden jelek szerint a jövöben is lesznek. Ennek a Diákasztalnak egyik elsörangú feladata az Erdélyben pusztuló magyarságnak megmentése olyan

${ }^{26}$ MNL HBML VIII. 1.b. 4.d. 449-1916/17. (A dokumentumokat - a sajátos helyesírás ellenére - betűhíven közöljük.)

${ }^{27}$ Az 1872-ben alapított egyetem müködésének 27. esztendeje az 1899-es év volt.

${ }^{28}$ Csűrös Ferenc közművelődési tanácsnok. 
magyar középosztálynak nevelésével, amelyik ellen tudjon állani az eloláhosodásnak, annak a folyamatnak, amelyet támogat ezen a területen minden intézmény még azzal is, hogy a magyarságot a teljes elhagyatottságnak érzésével gyengiti. Az erdélyi társadalomnak nemzetiségi elemei mind hatalmasan szervezett és erös, számos forrásból táplálkozó anyagi erökkel felruházott hátsó védelemre támaszkodhatnak. Ezzel szemben a magyarság föladata itt a lemondás, az állandó háttérbevonulás, a minden tekintetben a tisztán maga erejére való utaltság. Ennek a társadalomnak folyton azt a kardot kell megtoldani nem is egy, hanem igen sok lépéssel, amelyik mindig rövid és mindig rövidebb lesz, akár a szervezettséget, akár az anyagi eröket tekintjük is.

Mindez nem azt mondja, hogy aki magyart erre a területre állitott a Mindenható Isten, hát az a küzdelmet föladja, hanem azt mindenesetre, hogy a küzdelmet forma és eszközök tekintetében az idevaló viszonyokhoz alkalmazza.

A kolozsvári Egyetemi Diákasztalnak összes évi jövedelme akkor, amikor annak vezetése a mostani felügyelöbizottságnak kezeibe került, 1800 forint volt. Tehát bérlö kezeibe jutott és az természetesen üzleti módon használta ki. Ezen változtatni kellett és házikezelésbe vevödött az intézmény úgy, hogy az évi kiadásai sem találtak fedezetet. Ezeket mind az intézmény munkájának segitségével kellett évröl-évre biztositani. Hozzájárulásra kellett birni az egyetemi ifjúságot, magát az egyetem Tanácsát, a vallás-és közoktatásügyi minisztériumot és azt a gyenge társadalmat is, amelyröl egy pár szóval megemlékeztem. Ide mellékelem ebböl az átmeneti időböl származó évi jelentésünket, amelyböl méltóztatik látni azt, hogy milyen intézkedéseknek és milyen szervezetnek a segitségével indultunk meg azon a göröngyös úton, amelyen eljutottunk a mai állapotokig. Hogy mit használhat ebböl a debreczeni Mensa, azt az igen tisztelt Professzor Úr legjobban meg fogja itélni. Én csak azt jegyzem meg, hogy az ifjuság köréböl alakitott Mensa-szövetség nem vált be és azt alig egy évi müködés után fel kellett oszlatnunk. Az a generáczió, amely azokat az iffakat nevelte, akikböl ez az elsö és utolsó Mensa-szövetség alakult, nagyon rosszul teljesitette feladatát. Igazán nem tudom, hogy milyen az az iffúság, amelylyel ott fognak dolgozni, mert hiszen ennek a qualitásától függ, hogy ez az intézmény ott beválik-e vagy nem.

Az Egyetemi Diákasztalnak Kolozsvárt Diákotthonnal való összeköttetése épen azoknak a szomorú tapasztalatoknak következménye volt, amelyet az ifjúsági Mensa-szövetséggel tettünk és ennek a Diákotthonnak szervezésénél már nagyon is szigorú elveket kellett követnünk.

Az elsö föladat volt, hogy a komoly munkát biztositsuk. Ezt szolgálta az, hogy egy lakószobába csak két hallgatót helyeztünk el, mert ha az egyik tanult, a másiknak hallgatnia kellett, s mert nem volt kivel beszéljen, tehát ô is tanult. Másodszor az is, hogy az intézmény élére egy fellow-ot állitottunk, aki egyáltalán nem volt ugynevezett fólïgyelo", hanem az ifjúságnak jóbarátja, aki minden hozzáfordulónak minden ügyében szivesen szolgált jó tanácsokkal. Ellenörzést csak annyiban gyakorolt, amennyiben minden, az intézet czéljaival el-

${ }^{29}$ Fellow, ebben az értelemben társat, barátot jelent, aki nem annyira pozíciójánál fogva, mint inkább tekintélyével, tapasztalatával emelkedik a hallgatók fölé. 
lentétes dologról tudomást vett és azt az elnökkel megbeszélte. A legfontosabb mindenesetre a fellow személye mert erre a feladatra csak feltétlen erös jellemü, e mellett nagy szivjóságú, sok belátással rendelkezó és jómodorú embernek kell lennie, tekintélyét kell, hogy a saját súlya, tudományos munkásságának értéke is föltétlenül emelje, mert az intézet szervezete kizárt minden fegyelmi eljárást. Uri családnak szervezödött, amely mindenkit szivesen lát kebelében, aki tiszteletben tartja a családnak szokásait, alkalmazkodik annak jóizléséhez, bensöséggel vesz részt annak életében, de a lehetölegnagyobb diszkréczióval és minden feltünés nélkül tisztán csak a család fejének intézkedése utján huzódik vissza mindazoktól, akik a fennt jelzett dolgokat tiszteltben nem tartják. Egyszerüen az ilyeneket többé nem fogadja; teszi pedig ezt tisztán a családfö jogának alapján, amely ellen fellebbezésnek helye nincs.

Méltóztatik látni, hogy már itt is kiemelódik a másik szempont, a társadalmi jóizlésnek és a bensöséges családi életnek ápolása.

A férfiember mint az erö képviselöje, természetétöl fogva durva és finomabbá azáltal válik, ha a gyengékkel érintkezésbe jut. Az igazi erö a gyengeség láttára hajlik csak meg a gyengeséggel szemben megnyilvánuló durvaságnál, a férfiatlanságnak határozottabb ismertetöjele nincsen.

Ezért honositotta meg a Diákotthon kebelében a vasárnap délutáni fogadóestélyeket intézményünk. Ezen a fogadóestélyeken jelentek meg a város úri családjai leányaikkal, és itt volt alkalma az ifjúságnak mivelt családoknak leányaival egy pár órát nemes és vidám szórakozásban eltöltenie. Ezeket az estélyeket este 9 órakor feltétlenül zártuk, mert hiszen mindenféle túlzásnak ellent mond a jóizlés. Könyvtárat és társalgótermet létesitvén ott egyrészt a közös munkát tettük lehetövé. Pl. orvosi vizsgálatokra való készülésnél a mikroszkopiumos tanulmányok közös elvégzését és több más hasonlót, amilyenek az idegen nyelvek gyakorlása stb., de ez a terem arra is szolgált, hogy akik épen nem tanultak s kicsit üdülni kivántak, lakótársaiknak zavarása nélkül tölthessék el az idöt.

Az összes helyiségekben tilos minden nemü kártyajáték, kapúzárás után minden bent nemlakónak el kell hagyni az épületet.

Ügyelünk arra, hogy az iffuság a szinházat használhassa s azért a vacsora már szinház [sic] elött kiszolgálandó. De minden apróbb dologra kitérni azt hiszem fölösleges. Ide mellékelek egy Házirendet is, ez is sok részletet elmond; a lényeges azonban az, hogy:

azt hisszük, hogy az iffúságnak az egyetemen meg kell kezdenie a felelösséggel járó munkát. Belé kell szoknia abba, hogy szabadságával úgy éljen, amint az reá és a közre nézve hasznos, meg kell tanulnia saját tapasztalásából, hogy mindenkinek a joga odáig terjed, ameddig másnak a jogkörébe bele nem vág, vagy az általános jogrendre zavarólag nem hat. Meg kell tanulnia a maga tapasztalásából, hogy hogyan kell a pénzzel bánnia, hogy rövidséget ne szenvedjen, és hogy mindig alkalmazkodni tudjon a saját vagyoni helyzetéhez; egyszóval annak a férfinak a gyakorlati iskoláját csinálja végig, akinek majd egy család fejévé kell válnia, egy nöt vezetnie kell, és egy családot úgy irányítania, hogy az mindig úgy anyagi, mint szellemi tekintetben harmonikus életet folytasson, és soha senkinek terhére ne váljon, hanem lehetöleg mindenkinek és a köznek is hasznára legyen. 
Ezt a czélt nem lehet elérni skatulyákba osztályozással, közös hálótermekkel, felügyelökkel, tanulási idöknek kiszabásával, órabeosztásokkal stb. Szóval azokkal a panaceákkal, ${ }^{30}$ amelyekkel a középiskolai internátusok dolgoznak, nem föképen akkor, amikor elsörangú követelmény az egyéniségnek és az ö eredeti sajátosságainak szabad kifejlését is szolgálni. Intézetünk tervezetében tehát a teljes polgári szabadságnak elve uralkodik. Ha valakinek tetszik, elöfizet a Mensán egész hónapra, ha nem tetszik, csak egy hétre vagy kettöre vagy háromra, ha ez se tetszik, minden nap külön fizetheti az ebédjét és a vacsoráját.

Sokszor megesik, hogy a hó elején, különösen elsö évesek egy nagyobb vendéglöben étkeznek, söt bizony olyan mulatságok is esnek, hogy elmegy a hó elején a nagyobb vendéglökben az egész havi pénz. Ezt a mi intézményünk egyáltalán nem akadályozza meg. Hiszen maga az élet és az üres tárcza a legjobb magyarázat arra, hogy kár volt igy osztani be a havi jövedelmet, és ezután a tapasztalás után nagyon jólfog a Mensa az ö rendszeres és jutányos ebédjeivel és vacsoráival. Ugyan igy járunk el más tekintetekben is. Szabály, hogy 10 órakor zárják a kapút, akinek tetszik kimaradhat, de ha késöbb jön haza, fizeti a kapúpénzt, ezzel tehát számolnia kell.

Nem türünk semmiféle izléstelenséget, lármát, durvaságot, de megtorló intézkedésünk teljességgel nincs; csak annyi, hogyha valaki ezeknek bármelyikét megcselekszi, kijelentjük, hogy mától kezdve legnagyobb sajnálatunkra az Egyetemi Diákasztal öt nem fogadhatja. Erröl senkinek tudomása nincs; az illetö, ha bennlakó, elhagyja lakását, ha pedig csak küntlakó, elmarad az étteremböl. Ugy látszik, mintha ez túlradikális lenne; az eredmények azonban megmutatták, hogy nem az, mert egyetemünknek volt 2500-on fölüli hallgatója is, mig a Mensán étkezök száma a 400-at alig haladta fölül; a hatás azonban, amelyet az intézmény az egész egyetemi iffúságra gyakorolt, kétségtelenül látható volt az általános miveltség, jómodor és kötelességtudás tekintetében, tehát szabályozó volt és más czélja nem is lehet. Az egyetemi tanárok bármikor a napi ár lefizetése ellenében ott ebédelnek vagy vacsoráznak a Mensában. Leülnek akár melyik asztal mellé. Megjegyzem, hogy kétféle étterem van; az egyikben hosszú asztalok, ahol 10 ember ülhet együtt, a másikban kis asztalok, amelyeknél 4 ember foglal helyet. Ez is azt szolgálja, hogy ki-ki a maga gusztusát kövesse, és tapasztalatokat tehessen a közös étkezés különbözö fajtáiban. A professzorok, ha megjelennek, és olyan asztalhoz ülnek, ahol más is ül, maguk mutatkoznak be a helyet foglalás után, saztán nyugodtan elbeszélgetnek az étkezés ideje alatt a velük együtt étkezö ifjakkal. Egészen természetes, hogy van bizony ilyen esetekben sokszor egy kis zavar, egy kis - söt néha nagy ügyetlenség is, de aztán másod-, harmadévessel már eféle meg nem esik.

A kezelés a szobák kiadásánál az idemellékelt prospektus szerint úgy történik, hogy a szülö kötelezi magát, hogy a prospektusba foglalt árak ellenében 9 hónapig fizetni fogja a bért, és abban az esetben, ha fia az intézetet elhagyná elöbb, úgy helyettest állit, de csak olyat, akit a lakótárs elfogad és a Diákasztal vezetösége is. Ha ilyet állitani nem tud, fizetési kötelezettsége mindaddig fönnáll, ameddig a Mensa maga a szobát másnak ki nem adja.

${ }^{30}$ Panacea: latin szó, varázsszert, mindent gyógyító, minden bajban használható csodaszert jelent. 
Az étkezésnél külön szelvénytömböket kapnak a hallgatók a reggelire, külön az ebédre és külön a vacsorára még pedig havonként és hetenként.

E jegytömbök szine hetenkint változó. Ujabban az ebéd és vacsora jegytömbök helyét kartonra nyomott állandó jegyekkel pótoltuk, csak a reggeli jegyeknél maradt meg a szelvényekböl álló tömbrendszer, minthogy a reggelinél az inspekcziósok ${ }^{31}$ még nem kötelesek megjelenni.

Legutóbb 8 hallgató kapott egészen ingyenes étkezést, 24 hallgató kapott féldijasat, és 24 kapott olyan kedvezményt, hogy 6 koronával olcsóbban kapta az étkezést, mint a teljes dijat fizetök. Ezek a kedvezményes hallgatók végzik az ellenörzést az ebédnél és a vacsoránál úgy, hogy minden hallgató, mikor az étkezésre jö, a ruhatárban helyetfoglaló két inspekczósnak köteles a belépésre jogositó jegyét fölmutatni, amire az egyik inspekcziós az elötte levö iven, amely a kiosztott jegyeknek számait tartalmazza, megjelöli a jelentkezönek a számát. Ezzel akadályozódik meg, hogy valaki egy nap kétszer ebédeljen vagy vacsoráljon. Azután az inspekcziósok egyike 4 pénzalakú réz-vagy bádogbárczát nyújjt át a jelentkezönek, melyek közül az egyikkel a kenyérért fizet t.i., amint belép a terembe ott kenyeres kosarakban szépen elrendezve 18 dekás fehér czipót kap, amelyet maga vesz ki, átadván a jegyét az ott ügyelö harmadik inspekcziósnak. A második bárczával fizet a kiszolgáló legénynek a levesért, a harmadik bárczával a második fogás és a negyedik bárczával a harmadik fogás ételért.

Miután a vacsora csak egy tál étel és egy czipó, tehát akkor csak két bárczát adnak ki a felmutatott számozott belépöjegy ellenében.

Az inspekczió egy félév alatt hetenként kétszer esik egy-egy teljesen ingyenesre, hetenkin egyszer a féldijasokra; a hat korona dijasokra még eddig egyszer sem volt szükségünk, mert nélkülük is el tudtuk látni az inspekcziót.

Az inspekczió kezdödik déli 12 órakor és tart délután 2-ig, az esti kezdödik este fél hétkor és tart fél 9-ig. A beosztásnál ügyelünk, hogy az inspekcziósok órabeosztásukkal az egyetemen összeütközésbe ne jöjjenek.

Mindennap a beszolgáltatott bárczákkal el kell számolnia a kiszolgáló legényeknek is, meg a kenyérinspekcziósoknak is. Innen állapitódik meg, hogy nem történt-e hiba vagy visszaélés. A reggeli jegyek szelvényeit - miután akkor inspekczósok nincsenek - a kiszolgáló legények veszik el, és ennek ellenében kapnak a konyhából reggelit. Ezeket tehát a konyha ellenörzi. A reggeli kávéból és egy 55 grammos tejes zsömlyéböl áll.

Ami a jegyeket és jegytömböket illeti, azokra nézve Dr. Ruttka tanácsjegyzö úr, ${ }^{33}$ aki egyetemünk quaestora mellett sokáig és nagy lelkesedéssel dolgozott a Mensa ügyekben is,

${ }^{31}$ Inspekcziós: latin eredetű kifejezés, ügyeletest, napi szolgálatost jelent.

32 Bárcza: ma már ritkán használt főnév, leginkább bizonyos pénzösszeg befizetését igazoló jegyek, nyomtatványok vagy érmék megnevezésére szolgált. A kolozsvári menza esetében a forrás szerint rézből vagy bádogból készült pénzalakú érmét jelentett.

33 Utalás Ruttka Ferenc egyetemi tanácsjegyzőre, aki mielőtt 1914. augusztus 31-én a megalakuló Debreceni Tudományegyetem tanácsjegyzőjévé kinevezték, 1903. május 1-jétől dolgozott a kolozsvári Ferenc József Tudományegyetem rektori hivatalában, 1907. április 16-tól pedig quaestori hivatali ellenőrként. Debrecenben az 1927. november 28-án bekövetkezett haláláig ő volt az egyetemi tanácsjegyző. - Az életrajzi adatok forrása: Mudrák József, Debreceni egyetemi lexikon 1914-1949, [Kézirat]. 
nagyon pontos fölvilágositásokat adhat, mert ö ezeknek a rendszerét ismeri, és általában az elszámolás kérdéseiben is sok becses utmutatást adhat.

Ha még esetleg valamire szükség lenne, méltóztassék csak hozzám fordulni, mindig különös szerencsémnek tartom, ha szolgálatára lehetek.

Megkülönböztetett tisztelettel

Kolozsvár, 1916. deczember hó 20-án.

Dr. Pósta Béla"

\section{Egyetemi Diákasztal (Mensa Academica) Kolozsvárt ${ }^{34}$}

„A kolozsvári egyetemen létesült Egyetemi Diákasztal czélja a szétszórva étkezö hallgatókat egyesiteni s ezáltal öket jó és olcsó étkezéshez juttatni.

A Diákasztal egy felügyelö bizottság igazgatása alatt áll, melynek tagjai: a) az egyetemi tanácstól a ny. r. tanárok közül kiküldött elnök és alelnök; b) az egyes tudománykarok és az ifjusági segélyegyletek által megválasztott egy-egy rendes és illetöleg egy-egy póttag: c) az egyetemi quaestor: d) a hölgybizottság elnöke.

A felügyelö bizottságot Kolozsvár város intelligens hölgyeiböl alakult állandó hölgybizottság támogatja, a melynek két-két tagja mindennap felváltva tart felügyeletet a konyha felett, s ellenörzi az étkek egészséges voltát, izléses elkészitését és kellö mennyiségben leendö kiszolgálását.

A Diákasztal ma az egyetem töszomszédságában (Petöfi - Egyetem és Fogoly-utcza sarkán) saját kétemeletes házában nyert elhelyezést, amelyben két hatalmas étterem, egyszerre 300 hallgató befogadására képes. ${ }^{35}$

Ugyanebben az épületben 42 hallgató számára 22 diákszoba áll rendelkezésre.

Minden egyes diákszoba 2 hallgató számára rendezödött be. A szobák bútorzata izléses, választékos és áll két ágyból, 2 ruhaszekrényböl, 2 éjjeli szekrényböl, 2 könyves polczból, 2 iróasztalból, 2 iróasztali székböl, 1 divánból, 1 diván elötti asztalból és két karosszékböl.

Ezekenek a diákszobáknak ára ágynemüvel, világitással és fütéssel együtt személyenkint 30 korona.

A felügyelö bizottság arra törekedett, hogy lehetöleg olyan otthont nyújtson az ifjaknak, a melylyel versenyezni Kolozsvárt semmiféle diáklakás nem képes, és e mellett mégis olcsó legyen.

A Diákasztal épülete 3 oldalról teljesen szabadon áll. A város legegészségesebb pontján és az egészségügy összes kivánalmainak megfelelöleg épült.

${ }^{34}$ MNL HBML VIII. 1.b. 4.d. 449-1916/17.

35 Az 1904. június 28-án kelt jelentés szerint az 1903/1904. tanévben a kolozsvári Mensa Academica a báró Bánffy Ernő tulajdonát képező Deák Ferenc u. 32. számú ház első emeltén volt elhelyezve, és 200 hallgató étkeztetésének a biztosítására volt alkalmas. Vö. Az Egyetemi Diákasztal fölügyelöbizottságának jelentése..., i. m., 3. és 9. 
E lakószobákban csak egyetemi polgár lakhatik. Az intézménynek nincs szorosan vett internátusi jellege. A bentlakóknak egy tanácsadó jóbarát (fellow) útmutatásokkal és jóakaratú támogatással állandó segitségükre van: ez az intézmény vezetöje, aki okleveles középiskolai tanár és az intézetben bennlakik.

A bentlakó hallgatóknak külön társalgótermek állnak rendelkezésére, ahol vendégeiket fogadhatják. Az intézetben elhelyezett fürdök is rendelkezésükre állnak.

Minthogy mindössze csak 44 hallgató lakhatik az intézetben, mindenki saját érdekében jár el, ha a bentlakásra minél elöbb jelentkezik. Jelentkezni lehet a Kolozsvári Egyetemi Diákasztal (Mensa Academica) Felügyelo" Bizottságánál Kolozsvár, Egyetem, régiségtár.

Tájékoztatásul ide iktatjuk, hogy aki nemcsak az épületben lakni, de a menzán étkezni is kiván, minö dijakat kell fizetnie, megjegyezvén, hogy a bentlakás senkit nem kötelez sem a bentétkezésre, sem a bentmosatásra. ${ }^{36}$

\begin{tabular}{|l|c|}
\hline Lakásbér egy hóra & 34 kor. \\
\hline Ebéd és vacsora egy hóra ${ }^{37}$ & 30 kor. \\
\hline Reggeli egy hóra & 6 kor. \\
\hline Ozsonna egy hóra & 6 kor. \\
\hline Mosatás egy hóra gallér és kézelötisztitás nélkül & 5 kor. \\
\hline
\end{tabular}

Megjegyezzük, hogy étkezésre lehet elöfizetni egy hétre, két hétre és három hétre is. A lakásnál azonban a fizetési kötelezettség kilencz hóra tart, vagyis szept. hó 5-töl junius hó 5-ig. A lakások havibérét, minden hó 5-én elöre kell fizetni. Ötödikén azért, hogy az olyan hallgatók, akiknek a szülei 1-én kapják javadalmaikat, 5-igakadálytalanúl megküldhessék a szükséges házbért.

A lakótárs és az intézet vezetöségének beleegyezésével a szobát bérlo" hallgató maga helyett helyettest is állithat, aki azonban csak egyetemi hallgató lehet.

A Felügyelö Bizottság fenntartja magának a jogot olyan házirend megállapitására, amelyet minden bentlakó tiszteletben tartani köteles."

${ }^{36}$ A forrás eredeti gépelt szövegében jól kivehető kézi javítás alapján megállapítható, hogy Pósta Béla levelének megírását röviddel megelőzően emelkedhetett a lakásbér 30 koronáról 34 koronára, az ebéd és vacsora havi díja 26 koronáról 30 koronára, valamint a mosatás 4-ről 5 koronára.

37 Debrecenben az Egyetemi Tanács 1917. január 29-i ülésén beterjesztett jelentés szerint az 1916/17-es tanév I. félévében az ebéd és vacsora díja az egész díjas (kedvezményes) tagok esetében havi 40 koronát tett ki, míg a féldíjas tagok esetében 20 koronát. Az 1916/17-es tanév II. félévében 9 hallgató étkezhetett teljesen ingyen a menzán, 11 pedig féldíjas kedvezményben részesült. E. T. Jegyzökönyvek 1916/17. tanév, VII. rendes ülés. 1917. január 29., 96. szám - MNL HBML VIII. 1/a. 1. k.

38 A reggeli Debrecenben az 1916/17-es tanév I. félévében a menzatagoknak külön havi 8 koronájába került. E.T. Jegyzökönyvek 1916/17. tanév, VII. rendes ülés. 1917. január 29., 96. szám - MNL HBML VIII. 1/a. 1. k. 
Kolozsvári Egyetemi Diákasztal Házirend ${ }^{39}$

„1. S. Az Egyetemi Diákasztal házában mindenkinek, úgy a bennlakó iffúságnak, mint az alkalmazottaknak úri házhoz méltó magaviseletet kell tanúsitania. Ugyanez áll az étkezésre bejáró ifjúságra is.

2. S. Zenélni a lakószobákban déli 12 órától 2 óráig és délután 5 órától 7 oraaig szabad, de csak úgy, ha a másik lakótárs is beleegyezik. A folyosókon és társalgókban azonban nem szabad.

3. S. Lakótársát mindenki maga választhatja. A lakótársak változása évközben csak közös megegyezés alapján s a titkár beleegyezésével lehetséges.

4. S. Kintornázni, házalni vagy koldulni nem szabad. Kutyát, macskát vagy baromfit senki sem tarthat.

5. S. Gyufát, szivar-és szivarka-csutkát a földre dobni, ablakpárkányra stb. tenni nem szabad. Erre valók a hamútartók.

6. S. Nem szabad a házban kártyázni, segyáltalán semmi szerencsejátékot folytatni. Az ez ellen vétóket nemcsak a lakástól fosztjuk meg - fizetési kötelezettségeik fenntartásával -, hanem az egyetemi hatóságnál is megtesszük ellene a feljelentést.

7. S. Nem szabad a butorokat s egyéb berendezési tárgyakat rongálni, bemocskolni, a falakat karczolásokkal, irással, rajzokkal vagy egyébként bepisztkitani. Az ez ellen vétökkel szemben a teljes kártéritési kötelezettségen kivül, az egyetem fegyelmi szabályai is érvényesülnek.

8. I. Az épület mindkét kapujának kulcsát a gépész-házmester kezeli, ki a fókaput reggel 6-kor nyitja, este 10-kor zárja; a mellékkaput reggel 7-kor nyítja, télen este 5-kor, nyáron 7-kor zárja.

9. S. A gépész-házmestert a kapunyitásért éjfél elött 10 fillér, éjfél után 20 fillér illeti meg. Ezt a dijat - ha nem szolgálati ügyben járnak - az alkalmazottak is fizetik.

10. I. A diákszobák tisztántartására és a bennlakó hallgatók ruhájának tisztitására külön komornyikok vannak. Ezeknek azonban egy nap és egy embernek csak egy öltöny ruhát - beleérte egy pár czipöt, egy kalapot, télen, tavaszszal és öszszel egy felöltöt - kötelességük takaritani. Ezeket a komornyikokat küldözgetni nem szabad.

11. I. A bennlakó hallgatók kisebb megbizásainak elvégzésére kifutószolgák állnak rendelkezésükre. Ezeknek azonban csak a komornyik útján kiadott hivásra és a megbizás elintézésének jelentésére szabad a szobákba bemennie. Ovakodni kell attól, hogy a kifutószolgákat egyesek túlságosan igénybe vegyék, mert ez a szolga elvonására vezethet.

12. $\mathbb{S}$. A szolgák a legelözékenyebb magatartást kötelesek tanusitani a hallgatókkal szemben. Viszont az utóbbiak nem kivánhatnak tölük a megszabott kötelességeken túllépö munkát. Gorombáskodni velük nemcsak nem illik, de nem is szabad.

13. $\mathbb{S}$. Az összes nöi és a konyhában levö férfi alkalmazottak a gazdasszony, a többi szolgák a gépész-házmester közvetlen felügyelete alatt állanak.

14. S. A takaritó és kifutó szolgákon, illetöleg az ezeknek felügyeletével megbizott gé-

${ }^{39}$ MNL HBML VIII. 1.b. 4.d. 449-1916/17. 
pész-házmesteren kivül a szolgaszemélyzet egyetlen tagjának sincs keresete az épület elsö és második emeletén. Ott tehát csak akkor mehet át, ha a mosókonyhában vagy a padláson dolga van.

15. S. Idegeneknek a lakószobákba és társalgókba bemenniök csakis a takaritó komornyik jelenlétében szabad és pedig csak valamelyik bennlakó hallgató vendégeként. Akit ennek ellenére ott találunk, azt kiutasitjuk, esetleg rendöri eljárást indítunk ellene. Kapuzárás után idegeneknek az épületben helye nincs.

16. $\mathbb{S}$. A lakószobák takaritása a délelött folyamán történik. E végett legkésöbb reggeli 9 órakor a szobák a lakók által rendelkezésre bocsátandók. Ellenkezö esetben nem szavatolunk, hogy a szobák a kellö idöre tiszták lesznek. Déli egy órára az összes szobáknak rendben kell lenniök.

17. S. Az emeleteken elhelyezett fürdöszobák használatáról külön beosztás intézkedik.

18. S. Az ifuiságnak az étkezö és iffúsági lakó-, illetöleg társalgóhelyiségeken kivül az épület más helyiségeiben semmi keresni valója nem lehet, tehát azokba belépnie sem szabad.

19. S. Úgy a világitásnál, mint a vizfogyasztásnál tartózkodni kell a tékozlástól. Ha senki sincs a szobákban, a villanyvilágitás kioltandó; a vizcsapokat használat után gondosan el kell zárni. Iskolai évenként egy-egy villanykörténél több nem igényelhetö. Az elrontott körte helyett ismét csak fémszálas alkalmazható.

20. S. A konyha és ahhoz tartozó mellékhelyiségek, valamint az étkezö helyiségek, ezek folyosói, a felügyelö-hölgyek szobája, ruhatár és az ezekhez tartozó folyosók, továbbá a mosókonyha és ennek mellékhelyiségei tisztántartásáról a gazdasszony gondoskodik.

A kazánház, a hozzátartozó helyiségek és lépcsök, valamint a lépcsöház tisztántartása a gépész-házmester feladata.

Az alkalmazottak a nekik kiutalt lakásrészek tisztántartásáról maguk gondoskodnak.

Az itt felsoroltak tekintetében azonban a titkár szükség esetén ettöl eltéröen is rendelkezhetik.

21. S. A lakás és mosási dijak minden hónap 5-ig mulhatatlanul befizetendök a titkárnál. A bennlakásra felvett hallgatók bérfizetési kötelezettsége 9 hónapig tart, vagyis a felvett hallgató évközben fel nem mondhat. Rendkivüli méltánylást érdemlö esetekben a titkár megengedheti azonban, hogy a lakását, az arra vonatkozó jogokkal és kötelezettségekkel évközben is átruházhassa más egyetemi hallgatóra, ha lakótársa abba beleegyezik. Biztositékúl minden szülö, illetöleg gyám kötelezö nyilatkozatot ad.

22. $\mathbb{S}$. Az ágynemüek kicserélését minden hónap 1. és 15. napján a gépész-házmester felügyelete alatt, a takaritó szolgák végzik.

23. S. A bennmosató hallgatók fehérnemüjét minden vasárnap délután 2 órakor veszik át, elismervény ellenében. A kimosott fehérnemüt szombaton délután adják át, az elismervény visszaadása ellenében.

24. S. Az Egyetemi Diákasztal étkezö helyiségeiben csakis egyetemi polgárok, illetöleg azok étkezhetnek, kik az egyetemre vidékröl jönnek vizsgázni. Az étkezö helyiségekben csendes, ildomos magaviseletet kell tanusitani. 
25. S. Az étkezési dijakat minden iskolai évre, szükség esetén félévre a felügyelö bizottság állapitja meg és hirdeti ki.

26. $\mathbb{S}$. Az étkezésre jogositó jegyeket az egyetemi quaesturában kell váltani. Egy napi étkezésre szóló jegyek az étkezö helyiségben válthatók. A befizetett étkezési dij ellenében a hallgatók nyugtatót nem, csak a megfelelo" jegyeket kapják; ellennyugtatót azonban kell adniok. A heti és havi jegyek érvényessége csak a kiváltás után való napon kezdödik.

27. S. Az étkezés ideje: reggelizés: $7-9$; ebéd 12 1/4-2; vacsora $1 / 27-1 / 2$ 9. Joga van a felügyelö bizottság elnökének arra, hogy kivételes esetekben (pl. házi mulatságok stb. alkalmával) az étkezés idejét megváltoztassa. A rendes idötöl való eltérést minden alkalommal, megfelelö módon, elöre közzéteszi.

28. S. Az étkezésnél a rendre azzal külön megbizott egyetemi hallgatók ügyelnek. Ezek udvarias felszólitásának engedelmeskedni kell.

29. S. Az étkezö helyiségekben csak magyarul szabad beszélni, aki ez ellen vét, azt azonnal és örökre kitiltjuk összes helyiségeinkböl.

30. S. A bennlakó hallgatók és alkalmazottak számára postán érkezö küldeményeket - a mennyiben az érdekeltek a postahivatalnál másképen nem intézkednek - a gépész-házmester veszi át, és kézbesiti a czimzetteknek. A közönséges küldeményeket egyszerüen átadja, az ajánlott és értékküldeményekröl azonban hiteles könyvet vezet, melyben a czimzett az átvételt elismerni tartozik.

A gépész-házmester a közönséges és ajánlott levelekért kézbesitési dijat nem szed. Az utalványokért azonban 10 fillér, a csomagokért 14 fillér illeti meg; négy fillérrel több, mint a mennyit fizetnie kell a m. kir. postának. Alkalmazottak csak a postának járó dijakat fizetik.

31. S. A házirend ellen vétök eredménytelen figyelmeztetés után az Egyetemi Diákasztaltól örökre kitilthatók. Szükség esetén az egyetem fegyelmi szabályzatának rendelkezései is alkalmazhatók velük szemben.

32. S. Minden panaszt elsö sorban a titkárral kell közölni, ki e végett megállapitott idöben hivatalos órát tart. Második és utolsó fokon a felügyelö bizottság, illetöleg annak elnöke rendelkezik. Névtelen feljelentések nem méltók a figyelemre." 